\title{
Honey as a Source of Environmental DNA for the Detection and Monitoring of Honey Bee Pathogens and Parasites
}

\author{
Anisa Ribani ${ }^{1,2}$, Valerio Joe Utzeri ${ }^{1,2}$, Valeria Taurisano ${ }^{1}$ and Luca Fontanesi ${ }^{1, *(1)}$ \\ 1 Department of Agricultural and Food Sciences, University of Bologna, Viale Giuseppe Fanin 46, \\ 40127 Bologna, Italy; anisa.ribani2@unibo.it (A.R.); valeriojoe.utzeri2@unibo.it (V.J.U.); \\ valeria.taurisano2@unibo.it (V.T.) \\ 2 GRIFFA s.r.l., Viale Giuseppe Fanin 48, 40127 Bologna, Italy \\ * Correspondence: luca.fontanesi@unibo.it; Tel.: +39-051-2096535
}

Received: 29 July 2020; Accepted: 13 August 2020; Published: 15 August 2020

\begin{abstract}
Environmental DNA (eDNA) has been proposed as a powerful tool to detect and monitor cryptic, elusive, or invasive organisms. We recently demonstrated that honey constitutes an easily accessible source of eDNA. In this study, we extracted DNA from 102 honey samples (74 from Italy and 28 from 17 other countries of all continents) and tested the presence of DNA of nine honey bee pathogens and parasites (Paenibacillus larvae, Melissococcus plutonius, Nosema apis, Nosema ceranae, Ascosphaera apis, Lotmaria passim, Acarapis woodi, Varroa destructor, and Tropilaelaps spp.) using qualitative PCR assays. All honey samples contained DNA from $V$. destructor, confirming the widespread diffusion of this mite. None of the samples gave positive amplifications for N. apis, A. woodi, and Tropilaelaps spp. M. plutonius was detected in $87 \%$ of the samples, whereas the other pathogens were detected in $43 \%$ to $57 \%$ of all samples. The frequency of Italian samples positive for P. larvae was significantly lower (49\%) than in all other countries (79\%). The co-occurrence of positive samples for L. passim and A. apis with N. ceranae was significant. This study demonstrated that honey eDNA can be useful to establish monitoring tools to evaluate the sanitary status of honey bee populations.
\end{abstract}

Keywords: Apis mellifera; DNA analysis; epidemiology; health; Lotmaria passim; Melissococcus plutonius; Nosema ceranae; pathology; Tropilaelaps; Varroa destructor

\section{Introduction}

Environmental DNA (eDNA), defined as DNA extracted from environmental- or organismal-related specimens or matrixes, has been proposed as a powerful tool to detect and monitor cryptic, elusive, or invasive organisms, including parasites and many other pathogens that might be difficult to sample or to identify-also extending or facilitating the possibility to evaluate their distribution, even over time and geographic areas [1,2]. Environmental DNA approaches vary according to the objective, the organisms and, in turn, the methods of specimen collection, DNA isolation, or enrichment for targeted or metagenomics analyses [3-5]. The use of eDNA has been recently proposed in the apiculture sector for several purposes [6,7].

The problems determined by the global collapse of honey bee colonies, caused by the co-occurrence of debilitating factors, including environmental stressors and the increased frequency and intensity of chronic diseases, has raised the attention on disease monitoring approaches and pathogen identification methods [8,9]. Prognostic eDNA in the honey bee production systems is detectable in the debris collected from the bottom of the beehive. This material has been proposed as the source of simple and 
non-invasive collectable specimens useful to detect pathogens and assess the health status of honey bee colonies [10-13].

Honey constitutes another easily accessible source of eDNA useful for pathogen detection and honey bee epidemiological studies. For example, several authors proposed polymerase chain reaction (PCR) based-assays to identify the presence of Paenibacillus larvae and Melissococcus plutonius in naturally infected honey samples [14-17]. These are the two major infecting bacteria in honey bee colonies causing the American and the European foulbroods, respectively $[18,19]$.

Giersch et al. [20] detected the presence of DNA of two microsporidia, Nosema apis and N. ceranae, in honey sampled in Australia and suggested that the later species was introduced in this continent through either contaminated honey or pollen. These two microsporidia have been significantly associated with the occurrence of colony losses [21-28].

Ascosphaera apis is a widespread fungal pathogen of honey bees causing the chalkbrood disease [29] that is responsible for colony losses, mainly when combined with other stressing conditions, derived by the co-presence of microsporidia or mite parasites and derived viruses [30].

Other parasitic microorganisms associated with increased colony mortalities in combination with other health problems and pathogens are two species of trypanosomatids, Lotmaria passim and Crithidia mellificae, which have been frequently confused and can be distinguished only using molecular methods [31-34].

Among the honey bee parasites, the tracheal tarsonemid mite Acarapis woodi (an internal parasite of the bee tracheal system, distributed in almost all continents; [35]) can causes significant economic damages in some conditions, even if it is not usually considered a real problem despite its quite high prevalence in apiaries of some countries [36].

The ectoparasite mite Varroa destructor is far more damaging than the tracheal mite [35]. Varroasis is acknowledged as the worst pest for Apis mellifera colonies all over the world, and one of the main responsible for death and reduced populations of overwintering colonies, and a potential factor of colony losses [37,38]. In addition to this mite species, other parasitic mites of the genus Tropilaelaps (parasites of $A$. dorsata) have recently raised concern after they have expanded their natural hosts to include A. mellifera, after this bee was introduced to Asia [39]. Invasion of Tropilaelaps mites in Europe and United States would likely be very damaging for the western apiculture, considering the higher reproduction rate and shorter life cycle that these parasites have than $V$. destructor [40]. To face this emerging threat, monitoring and detection systems have been developed to prevent the introduction of Tropilaelaps mites in areas outside Asia, the natural range of these species [41,42].

In this study, we used honey of different botanical and geographical origins as a source of eDNA to detect some of the most important pathogens and parasites of honey bees. We tested and developed qualitative PCR methods to identify two bacteria, P. larvae and M. plutonius, two microsporidia, $N$. apis and N. ceranae, one fungus, A. apis, one trypanosomatidae, L. passim, and three arthropod parasites, A. woodi, V. destructor and Tropilaelaps spp. The methods applied in this study expanded the possibility to evaluate the occurrence and prevalence of honey bee infecting and parasitizing agents by investigating an unconventional specimen (i.e., honey) than can be useful for epidemiological analyses and monitoring purposes.

\section{Materials and Methods}

\subsection{Honey Samples}

Honey samples were purchased from trade markets or were directly provided by beekeepers. These samples were not from a single hive as they derived by the routine procedures for their preparations and packaging into the final commercialized container or bin. A total of 102 honey samples were collected from European countries (n. 87), North, Central, and South American countries (n. 8), Asian countries (n. 5), African, and Oceanian countries (n. 1 for each continent). The European honey samples were from eight countries (n. 3 from Croatia, n. 4 from Finland, n. 2 from France, n. 1 
from Greece, n. 1 from Hungary, n. 74 from Italy, n. 1 from Serbia, n. 1 from The Netherlands). The honey samples from the American regions were from USA (n. 3), Mexico (n. 1), Guatemala (n. 1), Brazil (n. 2), and Chile (n. 1). Asian samples were from China (n. 3), India (n. 1), and Japan (n. 1). The African sample was from Ethiopia and the Oceanian sample was from New Zealand. The year of production of the analysed honey samples ranged from 2004 to 2018 (Figure S1). For 13 samples, the precise year of production was not declared, but according to the collected information, it might be between 2015 and 2017. A total of 60 samples had monofloral and 32 had polyfloral origin, whereas 10 were honeydew honey samples. Table S1 reports the list of samples, including their origin and the year of production.

\subsection{DNA Extraction from Honey Samples}

DNA was extracted from each honey following the protocol previously described [43]. Briefly, for each sample, a total of $50 \mathrm{~g}$ of honey was divided into four $50 \mathrm{~mL}$ tubes ( $12.5 \mathrm{~g}$ for each tube) then $37.5 \mathrm{~mL}$ of ultrapure water was added to each tube. These tubes were vortexed and then incubated at $40{ }^{\circ} \mathrm{C}$ for $30 \mathrm{~min}$. In the subsequent step, the tubes were centrifuged for $25 \mathrm{~min}$ at $5000 \times \mathrm{g}$ at room temperature and the supernatant was discarded. The obtained pellet was resuspended in $5 \mathrm{~mL}$ of ultrapure water and the content of the four tubes was merged in one and then diluted again with ultrapure water. After another centrifugation step ( $25 \mathrm{~min}$ at $5000 \times g$ at room temperature), the supernatant was discarded and the pellet was resuspended in $0.5 \mathrm{~mL}$ of ultrapure water. Then, $1 \mathrm{~mL}$ of CTAB extraction buffer [2\% (w/v) cetyltrimethylammonium bromide; $1.4 \mathrm{M} \mathrm{NaCl} ; 100 \mathrm{mM}$ Tris-HCl; $20 \mathrm{mM}$ EDTA; pH 8] and $5 \mu \mathrm{L}$ of RNase A solution $(10 \mathrm{mg} / \mathrm{mL})$ were added to each honey pre-treated sample and incubated for $10 \mathrm{~min}$ at $60^{\circ} \mathrm{C}$. After the incubation, $30 \mu \mathrm{L}$ of proteinase $\mathrm{K}(20 \mathrm{mg} / \mathrm{mL})$ were added and the mix was incubated at $65^{\circ} \mathrm{C}$ for $90 \mathrm{~min}$ with gentle mixing. Cooled samples at room temperature were centrifuged for $10 \mathrm{~min}$ at $16,000 \times g$. After the centrifugation, $700 \mu \mathrm{L}$ of the supernatant was transferred in a tube containing $500 \mu \mathrm{L}$ of chloroform/isoamyl alcohol (24:1) and mixed by vortexing. This step was followed by a centrifugation for $15 \mathrm{~min}$ at $16,000 \times g$ at room temperature. The supernatant was transferred in a new $1.5 \mathrm{~mL}$ tube and the DNA was precipitated with $500 \mu \mathrm{L}$ of isopropanol and washed with $500 \mu \mathrm{L}$ of ethanol $70 \%$. Finally, pellets were rehydrated with $30 \mu \mathrm{L}$ of sterile water and stored at $-20{ }^{\circ} \mathrm{C}$ until PCR analyses.

Extracted DNA was quality checked using the NanoPhotometer IMPLEN P300 (Implen GmbH, Munchen, Germany) and visually evaluated by 1\% agarose gel electrophoresis in TBE 1X buffer, after staining with 1X GelRed Nucleic Acid Gel Stain (Biotium Inc., Hayward, CA, USA).

\subsection{PCR Analyses}

PCR analyses were carried out using the PCR primer pairs reported in Table 1 . To assess the possibility to successfully amplify DNA fragments from the extracted DNA, we first verified if amplification could occur for honey bee DNA using primers designed on the mitochondrial DNA (mtDNA) region [44]. Primer pairs used in this study that targeted sequences of Paenibacillus larvae (two primer pairs) Melissococcus plutonius (two primer pairs) Nosema apis (one primer pair), N. ceranae (one primer pair), Ascosphaera apis (one primer pair), Lotmaria passim (one primer pair), Acarapis woodi (two primer pairs), and Varroa destructor (two primer pairs) were described by other authors (Table 1). Primers to detect the presence of Tropilaelaps spp. were designed in this work on the mtDNA sequence of Tropilaelaps clareae to target a region of the mitochondrial DNA Cox1 gene that, according to the available sequence information in GenBank, was conserved only in the Tropilaelaps genus (Table 1). All selected primer pairs were expected to amplify DNA fragments of $<300 \mathrm{bp}$ as the highly degraded honey DNA limits the possibility to successful amplify larger fragments [45]. 
Table 1. Information on PCR primers and PCR conditions used in this study to amplify DNA extracted from the 102 honey samples reported in Table S1.

\begin{tabular}{|c|c|c|c|c|c|c|}
\hline Species & Primer Name ${ }^{1}$ & Primer Sequences $\left(5^{\prime}-3^{\prime}\right)$ : Forward and Reverse ${ }^{2}$ & Size in Bp & Amplified Region & $\mathrm{Ta}^{\circ} \mathrm{C}^{3}$ & Reference \\
\hline Apis mellifera & $\begin{array}{l}\text { AM_Forward } \\
\text { AM_Reverse }\end{array}$ & $\begin{array}{l}\text { GGCAGAATAAGTGCATTG } \\
\text { TTAATATGAATTAAGTGGGG }\end{array}$ & C 85, M 139, A $153^{4}$ & mtDNA COI-COII & 51 & [44] \\
\hline Paenibacillus larvae & $\begin{array}{l}\text { AF_6f } \\
\text { AF-7r }\end{array}$ & $\begin{array}{l}\text { GCAAGTCGAGCGGACCTTGT } \\
\text { TCGTCGCCTTGGTAAGC }\end{array}$ & 237 & $16 \mathrm{~S}$ rRNA & 63 & [14] \\
\hline Paenibacillus larvae & $\begin{array}{l}\text { Han233PaeLarv16S_F } \\
\text { Han233PaeLarv16S_R }\end{array}$ & $\begin{array}{l}\text { GTGTTTCCTTCGGGAGACG } \\
\text { CTCTAGGTCGGCTACGCATC }\end{array}$ & 233 & $16 \mathrm{~S}$ rRNA & 59 & {$[46]$} \\
\hline Melissococcus plutonius & $\begin{array}{l}\text { MeliFORa } \\
\text { MeliREVa }\end{array}$ & $\begin{array}{l}\text { GTTAAAAGGCGCTTTCGGGT } \\
\text { GAGGAAAACAGTTACTCTTTCCCCTA }\end{array}$ & 281 & $16 \mathrm{~S} \mathrm{rRNA}$ & 63 & [36] \\
\hline Melissococcus plutonius & $\begin{array}{l}\text { Mp_Arai187_F } \\
\text { Mp_Arai187_R }\end{array}$ & $\begin{array}{l}\text { TGGTAGCTTAGGCGGAAAAC } \\
\text { TGGAGCGATTAGAGTCGTTAGA }\end{array}$ & 187 & NapA & 59 & {$[47]$} \\
\hline Nosema apis & $\begin{array}{l}\text { Nose_apis_chen_F } \\
\text { Nose_apis_chen_R }\end{array}$ & $\begin{array}{l}\text { CCATTGCCGGATAAGAGAGT } \\
\text { CCACCAAAAACTCCCAAGAG }\end{array}$ & 269 & SSUrRNA & $54-60^{5}$ & {$[48]$} \\
\hline Nosema ceranae & $\begin{array}{l}\text { Nose_cera_chen_F } \\
\text { Nose_cera_chen_R }\end{array}$ & $\begin{array}{l}\text { CGGATAAAAGAGTCCGTTACC } \\
\text { TGAGCAGGGTTCTAGGGAT }\end{array}$ & 250 & SSUrRNA & 58 & [48] \\
\hline Lotmaria passim & $\begin{array}{l}\text { LpCytb_F1 } \\
\text { LpCytb_R1 }\end{array}$ & $\begin{array}{l}\text { CGAAGTGCACATATATGCTTTAC } \\
\text { GCCAAACACCAATAACTGGTACT }\end{array}$ & 247 & mtDNA cyt b & 59 & [34] \\
\hline Ascosphaera apis & $\begin{array}{l}\text { AscosFORa } \\
\text { AscosREVa }\end{array}$ & $\begin{array}{l}\text { TGTGTCTGTGCGGCTAGGTG } \\
\text { GCTAGCCAGGGGGGAACTAA }\end{array}$ & 136 & $18 \mathrm{~S}$ rRNA & 61 & [36] \\
\hline Acarapis woodi & $\begin{array}{l}\text { Acarap_cox1_F1 } \\
\text { Acarap_cox1_R1 }\end{array}$ & $\begin{array}{l}\text { CAGTAGGGCTAGATATCGATACCCGAGCTT } \\
\text { TGAGCTACAACATAATATCTGTCATGAAGA }\end{array}$ & 247 & mtDNA Cox 1 & $55-62^{5}$ & [49] \\
\hline Acarapis woodi & $\begin{array}{l}\text { Acarapis_cox1_F2 } \\
\text { Acarapis_cox1_R2 }\end{array}$ & $\begin{array}{l}\text { CGGGCCCGAGCTTATTTTACTGCTG } \\
\text { GCGCCTGTCAATCCACCTACAGAAA }\end{array}$ & 162 & mtDNA Cox 1 & $55-62^{5}$ & [50] \\
\hline Varroa destructor & $\begin{array}{l}\text { Varr_cox1_181_F } \\
\text { Varr_cox1_181_R }\end{array}$ & $\begin{array}{l}\text { GCCTTTATTTGTATGGTCTG } \\
\text { TGGGTGTCCAAAAAATCA }\end{array}$ & 181 & mtDNA Cox 1 & 52 & [45] \\
\hline Varroa destructor & $\begin{array}{l}\text { Varr_cox1_148_F } \\
\text { Varr_Cox1_148_R }\end{array}$ & $\begin{array}{l}\text { TGGTATTATTTCTCATGTAATTTG } \\
\text { ATCAATATCTATTCCTACTGTAAA }\end{array}$ & 148 & mtDNA Cox 1 & 55 & [45] \\
\hline Tropilaelaps clareae $^{6}$ & $\begin{array}{l}\text { Tropi_cox1_F } \\
\text { Tropi_cox1_R }\end{array}$ & $\begin{array}{l}\text { TATTTGTATGATCTGTCCTA } \\
\text { ATAATACCAAATCCTGGTA }\end{array}$ & 214 & mtDNA Cox 1 & $54-60^{5}$ & This study \\
\hline
\end{tabular}

${ }^{1}$ Internal name of the forward and reverse primers. ${ }^{2}$ Sequence of the forward and reverse primers. ${ }^{3}$ Annealing temperature used in the PCR amplifications $\left({ }^{\circ} \mathrm{C}\right) .{ }^{4}$ The amplified fragment can have different size according to the mitochondrial lineage (A, C or M) as described in Utzeri et al. [44]. ${ }^{5}$ Range of the tested annealing temperature. ${ }^{6}$ The PCR assay was designed on the mitochondrial DNA sequence of Tropilaelaps clareae (GenBank accession no. EF025461). However, it is not specific for this species, as according to the sequence alignment with the corresponding region of other Tropilaelaps species, these primers can also amplify other species of this genus (i.e., T. mercedesae, T. thaii and T. koenigerum) due to 100\% identity of their mtDNA sequences in the primer regions. For this reason, the assay was indicated to amplify DNA of Tropilaelaps spp. The primer pair does not amplify $V$. destructor DNA. 
PCR analyses used one primer pair for each reaction (single PCR analyses). PCR were performed on a 2700 Thermal Cycler (Life Technologies, Waltham, MA, USA) in a total volume of $20 \mu \mathrm{L}$ including $50 \mathrm{ng}$ of isolated DNA and using KAPA HiFi HotStart Mastermix (Kapa Biosystems, Wilmington, MA, USA) with 10 pmol of each primer and adopting the following PCR profile: initial denaturation step at $95{ }^{\circ} \mathrm{C}$ for $3 \mathrm{~min}$, then 35 cycles of alternate temperatures $\left(20 \mathrm{~s}\right.$ at $98{ }^{\circ} \mathrm{C}, 15 \mathrm{~s}$ at the specific annealing temperature for the different primer pairs as indicated in Table $1,30 \mathrm{~s}$ at $72{ }^{\circ} \mathrm{C}$ ), followed by a final extension step at $72{ }^{\circ} \mathrm{C}$ for $1 \mathrm{~min}$. Amplified DNA fragments were electrophoresed in $2.5 \%$ agarose gels in TBE 1X buffer and stained with 1X GelRed Nucleic Acid Gel Stain (Biotium Inc., Hayward, CA, USA). PCR was carried out at least twice for each primer pair/honey sample combination to confirm the results. Results of these PCR analyses are qualitative (presence or absence of amplification based on the expected DNA fragments).

\subsection{Sequencing and Data Analysis}

Three to seven PCR fragments obtained for each primer pairs from the respective positively amplified honey samples were sequenced. Amplified fragments (derived from $7 \mu \mathrm{L}$ of PCR product) were purified with $1 \mu \mathrm{L}$ of ExoSAP-IT ${ }^{\circledR}$ (USB Corporation, Cleveland, OH, USA) for 15 min at $37^{\circ} \mathrm{C}$ and then sequenced using the BrightDye ${ }^{\circledR}$ Terminator Cycle Sequencing Kit (NIMAGEN, Nijmegen, The Netherlands). Sequencing reactions were purified using EDTA $0.125 \mathrm{M}$, Ethanol 100\% and Ethanol $70 \%$, following a standard protocol, and then were loaded on an ABI3100 Avant Genetic Analyzer sequencer (Life Technologies) for the detection of DNA sequences. Obtained electropherograms were visually inspected and analysed using MEGA 7 [51] and BioEdit Sequence Alignment Editor v7.0.5 [52] software. BLASTN (http://www.ncbi.nlm.nih.gov/BLAST/) was used to compare and validate the attribution of the obtained DNA sequences to the expected amplified region and organism.

A two-tailed Fisher exact test was used to compare the frequency of positive and negative honey samples between countries or groups of countries. Means were compared using t-Student tests.

\section{Results}

DNA extracted from all honey samples was amplified for the Apis mellifera mtDNA targeted region and the obtained fragments were the expected ones [44]. That means that for all samples, DNA was successfully isolated and PCR amplification was not inhibited by any contaminants eventually left in the extracted DNA aliquots (spectrophotometer analyses confirmed this result: $\mathrm{A}_{260} / \mathrm{A}_{280}$ was always $>1.6$ ). Therefore, the DNA isolated from all honey samples was then amplified with the other 13 primer pairs in single PCR analysis to obtain information on the presence or absence of nine honey bee pathogens or parasites (Paenibacillus larvae, Melissococcus plutonius, Nosema apis, N. ceranae, Ascosphaera apis, Lotmaria passim, Acarapis woodi, Varroa destructor, and Tropilaelaps spp.). All sequenced fragments for the positively amplified honey samples corresponded to the targeted regions, confirming the specificity of the assays that were developed by other authors (Table 1).

Among the primers that produced positive results, the two primer pairs tested for P. larvae gave the same results (presence of amplification or absence of amplification) for $93 \%$ of the analysed samples, whereas the two primer pairs used to detect $M$. plutonius gave the same results for $95 \%$ of the investigated samples. As the final aim of this study was to obtain information on the presence of potential honey bee health threats, for these two pathogens, we then considered positive a honey sample if at least one or both primer pairs gave a positive amplification.

The two primer pairs tested for $V$. destructor and $A$. woodi were concordant in $100 \%$ of the analysed samples, but with opposite results. In the case of $V$. destructors, all 102 honey samples gave positive amplification, whereas in the case of $A$. woodi none of the 102 samples had any amplified fragment. Two other tested PCR assays, each designed for a different organism, did not evidence the presence of the targeted DNA in the extracted honey: N. apis and Tropilaelaps spp. were never amplified in all honey samples. 
Figure 1 shows the percentage of honey samples that contained DNA of the other pathogens and parasites (i.e., P. larvae, M. plutonius, N. ceranae, A. apis, and L. passim). This figure reports the results considering all 102 honey samples together or dividing them into two other groups: only Italian samples (n. 74) and samples from all other countries (n. 28). Melissococcus plutonius was detected in $87 \%$ of the analysed samples whereas the other pathogens were detected in $43 \%$ to $57 \%$ of all samples. Comparing the results obtained for the Italian samples with the results obtained for all non-Italian samples, significant difference was observed for P. larvae ( $p=0.0074$; two tailed Fisher exact test). The frequency of positive samples was significantly lower in Italy (49\%) than in all other countries considered all together (79\%). This result was also confirmed dividing the non-Italian samples in other two groups: samples from all other European countries (n. 13) and samples from all other continents (n. 15) which both had a higher frequency of positive samples for $P$. larvae $(77 \%$ with $p=0.075$ and $80 \%$ with $p=0.044$, respectively) when compared to the Italian samples. For the M. plutonius, N. ceranae, A. apis, and L. passim no significant differences between the Italian samples and the non-Italian samples were observed.

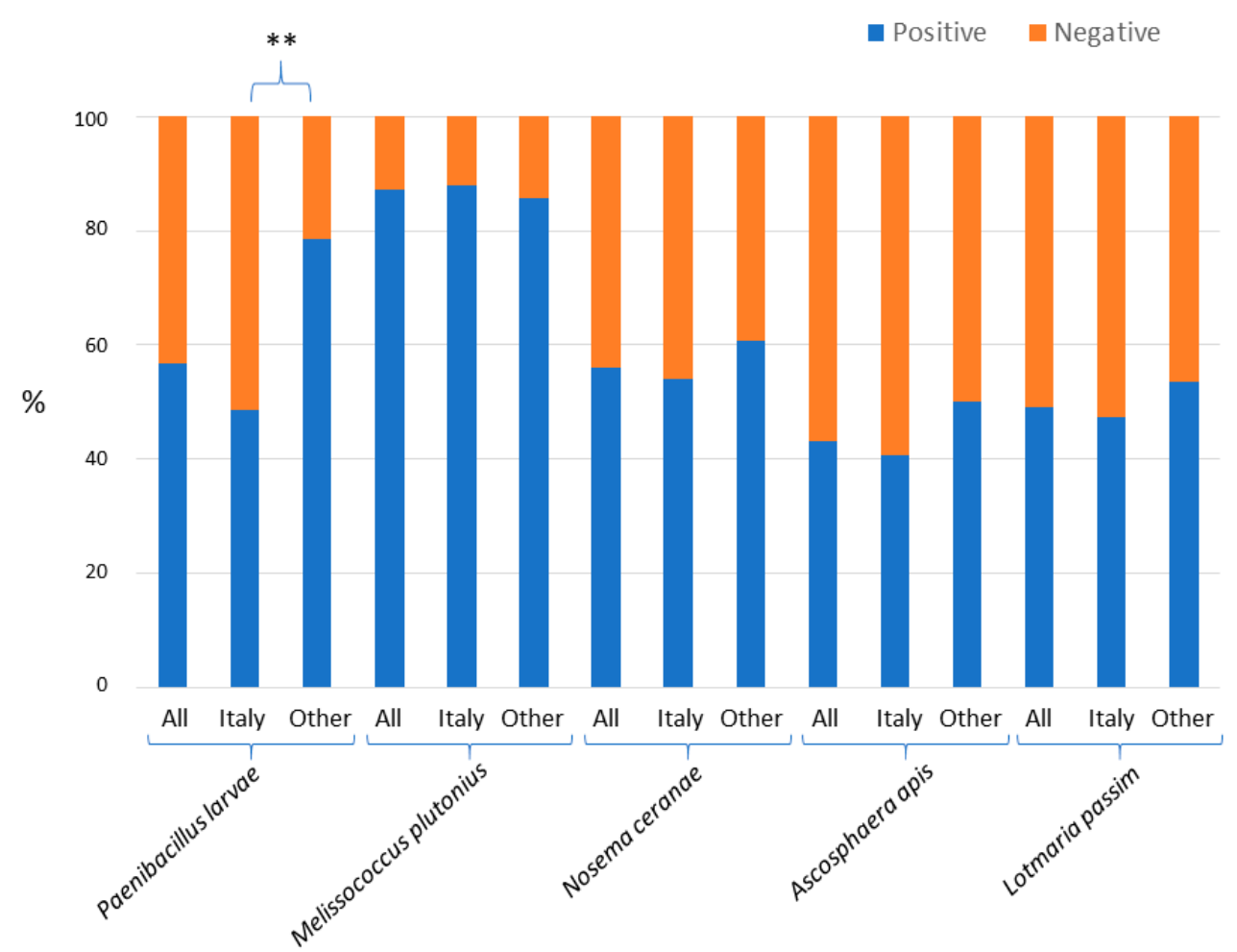

Figure 1. Frequency of the positive (presence of an amplified fragment, in blue) and negative (absence of an amplified fragment, in red) honey samples in the amplifications that targeted Paenibacillus larvae, Melissococcus plutonius, Nosema ceranae, Ascosphaera apis, and Lotmaria passim. "All" means that all 102 analysed samples were considered together; "Italy" means that only the 74 Italian samples were considered; "Other" means that only the remaining 28 non-Italian samples were considered. The two asterisks $\left({ }^{* *}\right)$ mean that the difference of positive honey samples between the two contrasted groups was highly significant $(p<0.01)$.

Considering the stratification of the results based on north and south of Italy, including the Sicily and Sardinia islands in this later geographic area (n. 30 vs. 31 samples; we excluded the regions of Central Italy for the low number of remaining samples), M. plutonius resulted significantly less frequent in samples from the north of Italy $(p=0.0125)$ whereas $L$. passim resulted more frequent in samples from this part of Italy $(p=0.074)$.

A total of 14 honey samples (10 of which from Italy) were positive for all pathogens and parasites (excluding those that were not detected in any samples). Both P. larvae and M. plutonius were 
co-amplified in $50 \%$ of all samples. Melissococcus plutonius was always the pathogen that occurred with higher frequency together with all other pathogens or parasites, as expected from its general higher frequency of positive samples. High frequency of co-amplification was observed for L. passim vs. N. ceranae ( $80 \%$; that means that $80 \%$ of the samples that were positive for L. passim were also positive for N. ceranae), for A. apis vs. N. ceranae (73\%) and for N. ceranae vs. L. passim (70\%). In these three cases, the co-occurrence of these pairs was statistically different from what would be expected considering the random distribution of each pathogen based on their general frequency of positive samples ( $p<0.001, p<0.01$, and $p<0.10$, respectively). Only three honey samples (all from Italy) did not show any amplification from all pathogens and parasites (except for $V$. destructor, that was detected in all samples). The distribution of the honey samples that gave amplified fragments for one to six pathogens/parasites is reported in Figure 2.

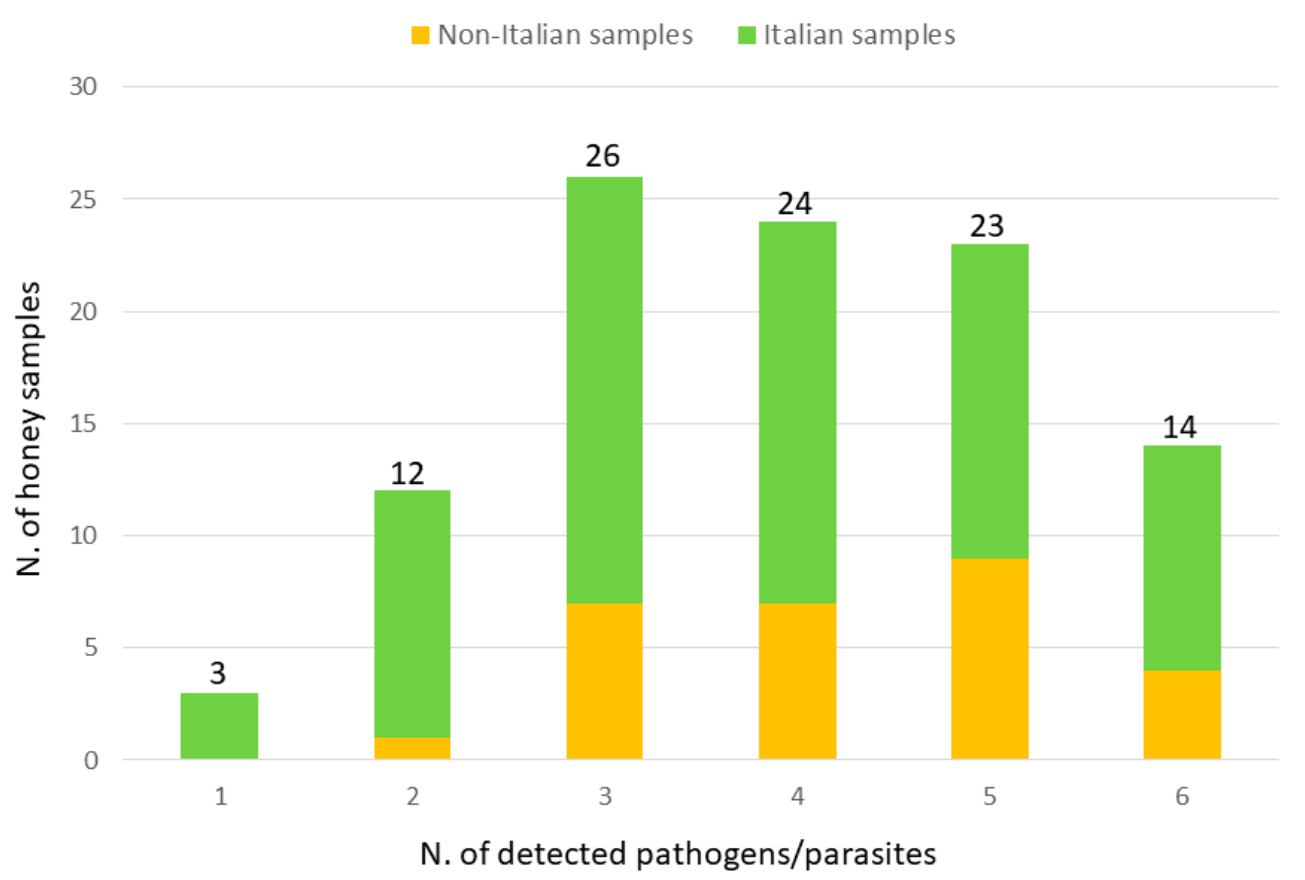

Figure 2. Number of honey samples that were positive for one to six pathogens/parasites differentiated between Italian samples (in green) and non-Italian samples (in orange). The total number of positive samples is reported at the top of each bar.

On average, the Italian samples were positive for 3.78 pathogens/parasites (standard deviation: 1.41) whereas for the non-Italian samples this mean was equal to $4.29( \pm 2.12)$. The two means differed at $p<0.10$.

The two oldest honey samples that were analysed (produced in the year 2004) were positive for V. destructor, P. larvae, and M. plutonius. Considering the year of production, N. ceranae, A. apis, and L. passim were first detected in an Italian honey produced in the year 2012. Due to the unequal distribution of the year of production and the limited number of old samples among those that were analysed (only eight samples were produced in 2013 or earlier), it was not possible to test if there were any differences in the number of positive samples over the years.

\section{Discussion}

Honey is a complex matrix that is mainly made by sugars but that contains several other components that can be explored to disclose interesting information that could be used for several purposes. One of the components, usually neglected or not considered at all, is the DNA that derives from all organisms that directly or indirectly contributed to its productions or that were part of the production systems or environments where the honey has been produced [6,7,43-45]. This eDNA also 
contains information on pathogens and parasites that can be present in the beehive ecological niche and that can represent a threat for the honey bee health.

In this study, we used qualitative PCR-based assays that targeted several pathogens and parasites to identify their presence in honey samples that were produced in Italy and in other countries from all continents. This work should be considered a pilot study that wanted to set up a methodology and evaluate the potential strengths and limits that the use of honey extracted DNA could have for the detection and monitoring of honey bee pathogens and parasites.

DNA from the honey bees is always contained in the honey they produce [44]. Therefore, to evaluate the quality of the extracted DNA and the possibility to use it for other tests, we first amplified the extracted nucleic acid with primers that targeted a region of the honey bee mtDNA that can be also used to detect the mitochondrial lineage of the A. mellifera that produced the honey [44]. As all samples gave the expected amplified products for this A. mellifera DNA region, the presence or absence of amplification for all other tested primer pairs that targeted nine pathogens or parasites is indicative of the presence or absence of their DNA in the investigated honey samples. DNA could be extracted and then amplified independently by the year of production. DNA from honey produced more than 15 years ago was successfully amplified. Therefore, honey can be used for retrospective analyses and can be stored for this purpose.

All tested assays are qualitative, and in this first pilot study, we did not evaluate the limit of detection for these pathogens that, however, have been already tested in some of the studies from which we derived the primer pairs that we used to amplify honey DNA. It will be interesting to transform the qualitative assays in quantitative analyses that could provide a more precise information and better evaluate the limit of detection from this source of DNA.

It is also worth to mention that the honey samples that we analysed might derive from more than one colony or beehive and probably from more than one apiary. Commercial honey is prepared by mixing the honey derived by more than one beehive. Therefore, the information that we obtained should be referred to the presence of the pathogens and parasites at a higher level than that is usually considered in epidemiological or monitoring studies that usually use the single beehive/colony as the unit of their analyses. The use of honey (particularly, when it does not derive from a single colony, as in our case) might provide information based on the health situation in many colonies or at the apiary level or even at the regional level, depending on the way in which the honey is finally packaged and commercialized. This is an advantage for global monitoring purposes but it could not be considered useful for the punctual health evaluation of a single colony or beehive, that instead could be obtained by traditional approaches or, eventually, by analysing DNA of a single honeycomb (even if this later could not be considered practical in most cases).

The presence or absence of Paenibacillus larvae, Melissococcus plutonius, Acarapis woodi, and Varroa destructor in the 102 analysed honey samples was verified using two primer pairs for each targeted organism, obtaining always or for most samples the same results. Some differences in the results of the two assays were observed for the detection of P. larvae and M. plutonius, probably due to differences in the limits of detection of these tests or for the presence of different strains across samples, having mutations in the primer regions that could affect the amplification efficiency. It will be interesting to further explore this issue not only for these two pathogens but also for the other pathogens and parasites that were amplified in this study by using only one primer pair.

As expected from the global diffusion of $V$. destructor, the DNA of this mite was amplified from all honey samples. The positive amplification obtained for all samples can confirm the high quality of the extracted DNA, as already derived by the successful amplification of the honey bee DNA. We already demonstrated that the sequence information derived by the amplified Varroa DNA fragments from honey samples and obtained using next generation sequencing can provide additional details on the presence of several mite strains in different countries [45]. This approach can be also applied for all other pathogens and parasites investigated in this study if the amplified regions are informative, 
i.e., they are expected to include sequence differences among strains or lines that could add other information to the derived eDNA.

For two other arthropod parasites, A. woodi and Tropilaelaps spp., and one microsporidium, Nosema apis, we did not identify any positive honey samples. The negative results obtained in these cases could be due to the failure of amplification of the tested primer pairs, even if for two organisms ( $A$. woodi and N. apis) we used primers that have been already extensively tested by other authors [48-50], two primer pairs were tested for $A$. woodi $[49,50]$ with the same negative results, and for all used primers for these three organisms, several PCR conditions were tested (Table 1).

The negative results for $A$. woodi are unexpected, according to the supposed world-wide distribution of this parasite reported by a few studies $[35,50,53,54]$. However, other studies indicated that the prevalence and diffusion of this honey bee tracheal mite is limited and potentially related to local conditions and factors [55-57] and this picture might better match the results we obtained. Other studies are needed to confirm the negative results derived by our approach based of the amplification of honey DNA by two different PCR assays that have been specifically designed to detect this species $[49,50]$.

On the other hand, the negative results for Tropilaelaps spp. were to some extent expected. That means that the absence of Tropilaelaps spp. amplified fragments indicates that these damaging mites [40] did not spread into the regions where we sampled the analysed honey. It could be also possible that the prevalence of mites of this genus was not relevant in these areas or it was under the detection limit of this analysis. It is also worth to mention that the assay we developed should be further tested using some positive honey samples. To be sure that honey DNA can be useful to capture the presence of these emerging parasites, it will be important to develop other PCR assays able to confirm these results. Anyway, even if the absence of Tropilaelaps spp. amplification is a good news, it further raises the attention to the usefulness of monitoring methods, like what we propose in this study, to prevent potential spreads in Europe or America where these mites would be probably very damaging to the apiculture sector [41].

Another pathogen that was never detected in the analysed samples was $N$. apis. The relevance of this microsporidium has been decreasing over the last decades that evidenced a corresponding increase of the infection prevalence and diffusion of $N$. ceranae, which has been suggested to replace N. apis $[27,58-60]$. Our results might confirm this general trend. Nosema ceranae was observed in more than $50 \%$ of the analysed samples further demonstrating the widespread and general prevalence of this obligate intracellular eukaryotic parasite.

Lotmaria passim, currently considered the predominant trypanosomatid species in A. mellifera host populations [33], was detected in about $50 \%$ of the honey samples, $80 \%$ of which were also positive for $N$. ceranae (and this co-occurrence was not derived by chance), confirming, to some extent, that its presence is usually associated with this microsporidium [34,61]. It is of course clear that, just by analysing honey DNA, is it not possible to establish a direct relationship between these two infection agents but this speculative deduction could open new opportunities to interpret the results when larger number of samples and specimens purposely collected for co-occurrence evaluations are investigated. It was also interesting to note that, stratifying the results of the Italian samples based on the two main geographic areas from which the largest number of samples were collected, L. passim occurred more frequently in the honey produced in the North of Italy than in that produced in the South of Italy. It will be important to increase the number of samples to confirm this preliminary evidence, that at present it does not have any clear explanations.

Ascosphaera apis, the agent of chalkbrood, was detected in more than $40 \%$ of all samples, confirming also for this entomopathogenic fungus the widespread distribution already known [29]. It will be important to understand if the DNA of $A$. apis derives from spores (which can have up to 15 years viability; [29]) or other materials, for the potential obvious implications derived by the possibility to further spread this disease through the exchange of honey. Similarly to what was discussed for L. passim, this fungus was detected in honey samples that in $73 \%$ of cases were also positive for 
N. ceranae, further suggesting a possible relationship determining the co-occurrence of these pathogens (of course taking into account what already discussed above).

Melissococcus plutonius was the most frequent pathogen amplified in the 102 honey samples, with $87 \%$ of positive samples. This Gram-positive lanceolate coccus is the agent of the European foulbrood, one of the most serious brood diseases of A. mellifera, for which there is still a poor understanding of disease epidemiology. It is already known that this bacterium is also present in healthy colonies, variants of this agent have been described and that the disease can occur in combination with other health threats [62-64]. Anyway, the very high frequency of positive samples is quite puzzling and needs to be further investigated to better understand its meaning, by taking into account the methodology that was used for this detection. The lower frequency of positive samples produced in the North of Italy than those produced in the South of Italy is also another matter of further evaluation, if confirmed by analysing a larger number of samples.

The general quite high percentage of positive honey samples for $P$. larvae indicates that not in all cases the presence of this pathogen might cause American foulbrood, as already reported $[65,66]$. The results of the amplifications for the agent of this disease showed that this bacterium was less frequent in the Italian samples (49\%) than in the non-Italian samples (79\%) and this difference was highly significant. The interpretation of this result is not simple and might be derived by different management systems and practices or environmental conditions that would limit the diffusion of this Gram-positive pathogenic bacterium in Italy compared to other parts of the world. This is in line to the lower mean number of pathogens/parasites detected in the Italian samples than in the non-Italian samples. These first results might speculatively indicate general better healthy conditions of the colonies in Italy than in other countries-a hypothesis that should be supported by other evidences. Another explanation for this difference could be due to the fact that non-Italian samples might be derived by a larger number of beehives or apiaries (most of them were purchased and not directly provided by the beekeepers; Table S1) than the Italian samples (most of which were provided directly by the beekeepers; Table S1), increasing the possibility to include honey derived by positive beehives or beehives in which this pathogen was present. If this would be a possible explanation of this result, it is not clear, however, why this difference between Italian and non-Italian honey samples was observed only for P. larvae and not also for other pathogens.

\section{Conclusions}

This study reported for the first time an extensive use of honey eDNA to design epidemiological and monitoring approaches for pathogens and parasites with the final objective of obtaining a general picture of the sanitary status of the honey bee populations at macro-levels (i.e., apiary, beekeeper, regions, countries, continents). Using this unconventional approach, we also obtained, for the first time, a comprehensive analysis (even if preliminary) of the distribution and frequency of several pathogens and parasites in Italy. It will be useful (i) to refine and improve the applied assays, adding methods to detect other pathogens, (ii) to increase the number of the analysed honey samples to improve the interpretation of the results, and (iii) to correlate the results derived by the DNA analyses with the situations in the colony and/or apiary and epidemiological data and distribution of pathogens and parasites in a region that could be obtained from direct observations. The results of this study on the distribution, co-occurrence and prevalence of some of the targeted pathogens and parasites should be interpreted, considering that honey bee health threats cannot be regarded as local problems.

Supplementary Materials: The following are available online at http://www.mdpi.com/2306-7381/7/3/113/s1, Figure S1: Distribution of the analysed honey samples based on the years of production. Table S1: List and details of the investigated honey samples.

Author Contributions: Conceptualization, L.F.; methodology, L.F., A.R., V.J.U.; formal analysis, A.R., V.J.U., V.T.; resources, L.F., V.J.U.; data curation, L.F., A.R., V.J.U.; writing-Original draft preparation, L.F.; writing-Review and editing, L.F., A.R., V.J.U., V.T.; visualization, L.F.; supervision, L.F.; project administration, L.F.; funding acquisition, L.F. All authors have read and agreed to the published version of the manuscript. 
Funding: This research was funded by University of Bologna RFO programme and by Regione Emilia-Romagna Misura F (DELIBERAZIONE DELL'ASSEMBLEA LEGISLATIVA DELLA REGIONE EMILIA-ROMAGNA 27 LUGLIO 2019, N. 216), BEE-RER project (2019-2020).

Acknowledgments: The authors thank Alberto Contessi and Gianfranco Naldi of Osservatorio Nazionale Miele, Lucia Piana of Lucia Piana srl and several beekeepers for the collaboration. This work was associated with the GRIFFA development activities.

Conflicts of Interest: The authors declare no conflict of interest. The funders had no role in the design of the study; in the collection, analyses, or interpretation of data; in the writing of the manuscript, or in the decision to publish the result.

\section{References}

1. Taberlet, P.; Coissac, E.; Hajibabaei, M.; Rieseberg, L.H. Environmental DNA. Mol. Ecol. 2012, 21, 1789-1793. [CrossRef] [PubMed]

2. Bohmann, K.; Evans, A.; Gilbert, M.T.; Carvalho, G.R.; Creer, S.; Knapp, M.; Yu, D.W.; De Bruyn, M. Environmental DNA for wildlife biology and biodiversity monitoring. Trends Ecol. Evol. 2014, 29, 358-367. [CrossRef]

3. Jerde, C.L.; Mahon, A.R.; Chadderton, W.L.; Lodge, D.M. "Sight-unseen” detection of rare aquatic species using environmental DNA. Conserv. Lett. 2011, 4, 150-157. [CrossRef]

4. Thomsen, P.F.; Kielgast, J.; Iversen, L.L.; Wiuf, C.; Rasmussen, M.; Gilbert, M.T.; Orlando, L.; Willerslev, E. Monitoring endangered freshwater biodiversity using environmental DNA. Mol. Ecol. 2012, 21, 2565-2573. [CrossRef] [PubMed]

5. Wilcox, T.M.; McKelvey, K.S.; Young, M.K.; Jane, S.F.; Lowe, W.H.; Whiteley, A.R.; Schwartz, M.K. Robust detection of rare species using environmental DNA: The importance of primer specificity. PLoS ONE 2013, 8, e59520. [CrossRef] [PubMed]

6. Bovo, S.; Ribani, A.; Utzeri, V.J.; Schiavo, G.; Bertolini, F.; Fontanesi, L. Shotgun metagenomics of honey DNA: Evaluation of a methodological approach to describe a multi-kingdom honey bee derived environmental DNA signature. PLoS ONE 2018, 13, e0205575. [CrossRef]

7. Bovo, S.; Utzeri, V.J.; Ribani, A.; Cabbri, R.; Fontanesi, L. Shotgun sequencing of honey DNA can describe honey bee derived environmental signatures and the honey bee hologenome complexity. Sci. Rep. 2020, 10, 9279. [CrossRef]

8. Dainat, B.; Evans, J.D.; Chen, Y.P.; Gauthier, L.; Neumann, P. Predictive markers of honey bee colony collapse. PLoS ONE 2012, 7, e32151. [CrossRef]

9. Lee, K.; Steinhauer, N.; Travis, D.A.; Meixner, M.D.; Deen, J. Honey bee surveillance: A tool for understanding and improving honey bee health. Curr. Opin. Insect Sci. 2015, 10, 37-44. [CrossRef]

10. Ward, L.; Brown, M.; Neumann, P.; Wilkins, S.; Pettis, J.; Boonham, N. A DNA method for screening hive debris for the presence of small hive beetle (Aethina tumida). Apidologie 2007, 38, 272-280. [CrossRef]

11. Ryba, S.; Titera, D.; Haklova, M.; Stopka, P. A PCR method of detecting American foulbrood (Paenibacillus larvae) in winter beehive wax debris. Vet. Microbiol. 2009, 139, 193-196. [CrossRef]

12. Ryba, S.; Kindlmann, P.; Titera, D.; Haklova, M.; Stopka, P. A new low-cost procedure for detecting nucleic acids in low-incidence samples: A case study of detecting spores of Paenibacillus larvae from bee debris. J. Econ. Entomol. 2012, 105, 1487-1491. [CrossRef] [PubMed]

13. Forsgren, E.; Laugen, A.T. Prognostic value of using bee and hive debris samples for the detection of American foulbrood disease in honey bee colonies. Apidologie 2014, 45, 10-20. [CrossRef]

14. Bakonyi, T.; Derakhshifar, I.; Grabensteiner, E.; Nowotny, N. Development and evaluation of PCR assays for the detection of Paenibacillus larvae in honey samples: Comparison with isolation and biochemical characterization. Appl. Environ. Microbiol. 2003, 69, 1504-1510. [CrossRef] [PubMed]

15. Lauro, F.M.; Favaretto, M.; Covolo, L.; Rassu, M.; Bertoloni, G. Rapid detection of Paenibacillus larvae from honey and hive samples with a novel nested PCR protocol. Int. J. Food Microbiol. 2003, 81, 195-201. [CrossRef]

16. McKee, B.; Djordjevic, S.; Goodman, R.; Hornitzky, M. The detection of Melissococcus pluton in honey bees (Apis mellifera) and their products using a hemi-nested PCR. Apidologie 2003, 34, 19-27. [CrossRef]

17. D'Alessandro, B.; Antúnez, K.; Piccini, C.; Zunino, P. DNA extraction and PCR detection of Paenibacillus larvae spores from naturally contaminated honey and bees using spore-decoating and freeze-thawing techniques. World J. Microbiol. Biotech. 2007, 23, 593-597. [CrossRef] 
18. Forsgren, E. European foulbrood in honey bees. J. Invertebr. Pathol. 2010, 103, S5-S9. [CrossRef]

19. Genersch, E. American Foulbrood in honeybees and its causative agent, Paenibacillus larvae. J. Invertebr. Pathol. 2010, 103, S10-S19. [CrossRef]

20. Giersch, T.; Berg, T.; Galea, F.; Hornitzky, M. Nosema ceranae infects honey bees (Apis mellifera) and contaminates honey in Australia. Apidologie 2009, 40, 117-123. [CrossRef]

21. Cox-Foster, D.L.; Conlan, S.; Holmes, E.C.; Palacios, G.; Evans, J.D.; Moran, N.A.; Quan, P.L.; Briese, T.; Hornig, M.; Geiser, D.M.; et al. A metagenomic survey of microbes in honey bee colony collapse disorder. Science 2007, 318, 283-287. [CrossRef] [PubMed]

22. Vanengelsdorp, D.; Evans, J.D.; Saegerman, C.; Mullin, C.; Haubruge, E.; Nguyen, B.K.; Frazier, M.; Frazier, J.; Cox-Foster, D.; Chen, Y.; et al. Colony collapse disorder: A descriptive study. PLoS ONE 2009, 4, e6481. [CrossRef] [PubMed]

23. Cornman, R.S.; Tarpy, D.R.; Chen, Y.; Jeffreys, L.; Lopez, D.; Pettis, J.S.; Van Engelsdorp, D.; Evans, J.D. Pathogen webs in collapsing honey bee colonies. PLoS ONE 2012, 7, e43562. [CrossRef] [PubMed]

24. Higes, M.; Martín-Hernández, R.; Botías, C.; Bailón, E.G.; González-Porto, A.V.; Barrios, L.; Del Nozal, M.J.; Bernal, J.L.; Jiménez, J.J.; Palencia, P.G.; et al. How natural infection by Nosema ceranae causes honeybee colony collapse. Environ. Microbiol. 2008, 10, 2659-2669. [CrossRef] [PubMed]

25. Higes, M.; Martín-Hernández, R.; Garrido-Bailón, E.; González-Porto, A.V.; García-Palencia, P.; Meana, A.; Del Nozal, M.J.; Mayo, R.; Bernal, J.L. Honeybee colony collapse due to Nosema ceranae in professional apiaries. Environ. Microbiol. Rep. 2009, 1, 110-113. [CrossRef]

26. Klee, J.; Besana, A.M.; Genersch, E.; Gisder, S.; Nanetti, A.; Tam, D.Q.; Chinh, T.X.; Puerta, F.; Ruz, J.M.; Kryger, P.; et al. Widespread dispersal of the microsporidian Nosema ceranae, an emergent pathogen of the western honey bee, Apis mellifera. J. Invertebr. Pathol. 2007, 96, 1-10. [CrossRef]

27. Higes, M.; Meana, A.; Bartolomé, C.; Botías, C.; Martín-Hernández, R. Nosema ceranae (Microsporidia), a controversial 21st century honey bee pathogen. Environ. Microbiol. Rep. 2013, 5, 17-29. [CrossRef]

28. Branchiccela, B.; Arredondo, D.; Higes, M.; Invernizzi, C.; Martín-Hernández, R.; Tomasco, I.; Zunino, P.; Antúnez, K. Characterization of Nosema ceranae genetic variants from different geographic origins. Microb. Ecol. 2017, 73, 978-987. [CrossRef]

29. Aronstein, D.A.; Murray, K.D. Chalkbrood disease in honeybees. J. Invertebr. Pathol. 2010, 103, $20-29$. [CrossRef]

30. Hedtke, K.; Jensen, P.M.; Jensen, A.B.; Genersch, E. Evidence for emerging parasites and pathogens influencing outbreaks of stress-related diseases like chalkbrood. J. Invertebr. Pathol. 2011, 108, 167-173. [CrossRef]

31. Ravoet, J.; Maharramov, J.; Meeus, I.; De Smet, L.; Wenseleers, T.; Smagghe, G.; De Graaf, D.C. Comprehensive bee pathogen screening in Belgium reveals Crithidia mellificae as a new contributory factor to winter mortality. PLOS ONE 2013, 8, e72443. [CrossRef] [PubMed]

32. Ravoet, J.; Schwarz, R.S.; Descamps, T.; Yañez, O.; Tozkar, C.O.; Martin-Hernandez, R.; Bartolomé, C.; De Smet, L.; Higes, M.; Wenseleers, T.; et al. Differential diagnosis of the honey bee trypanosomatids Crithidia mellificae and Lotmaria passim. J. Invertebr. Pathol. 2015, 130, 21-27. [CrossRef]

33. Schwarz, R.S.; Bauchan, G.; Murphy, C.; Ravoet, J.; De Graaf, D.C.; Evans, J.D. Characterization of two species of Trypanosomatidae from the honey bee Apis mellifera: Crithidia mellificae Langridge and McGhee, 1967 and Lotmaria passim n. gen., n. sp. J. Eukaryot. Microbiol. 2015, 62, 567-583. [CrossRef] [PubMed]

34. Stevanovic, J.; Schwarz, R.S.; Vejnovic, B.; Evans, J.D.; Irwin, R.E.; Glavinic, U.; Stanimirovic, Z. Species-specific diagnostics of Apis mellifera trypanosomatids: A nine-year survey (2007-2015) for trypanosomatids and microsporidians in Serbian honey bees. J. Invertebr. Pathol. 2016, 139, 6-11. [CrossRef] [PubMed]

35. Sammataro, D.; Gerson, U.; Needham, G. Parasitic mites of honey bees: Life history, implications, and impact. Ann. Rev. Entomol. 2000, 45, 519-548. [CrossRef] [PubMed]

36. Garrido-Bailón, E.; Higes, M.; Martínez-Salvador, A.; Antúnez, K.; Botías, C.; Meana, A.; Prieto, L.; Martín-Hernández, R. The prevalence of the honeybee brood pathogens Ascosphaera apis, Paenibacillus larvae and Melissococcus plutonius in Spanish apiaries determined with a new multiplex PCR assay. Microb. Biotechnol. 2013, 6, 731-739.

37. Guzmán-Novoa, E.; Eccles, L.; Calvete, Y.; Mcgowan, J.; Kelly, P.G.; Correa-Benítez, A. Varroa destructor is the main culprit for the death and reduced populations of overwintered honey bee (Apis mellifera) colonies in Ontario, Canada. Apidologie 2010, 41, 443-450. [CrossRef] 
38. Le Conte, Y.; Ellis, M.; Ritter, W. Varroa mites and honey bee health: Can Varroa explain part of the colony losses. Apidologie 2010, 41, 353-363. [CrossRef]

39. Anderson, D.L.; Morgan, M.J. Genetic and morphological variation of bee-parasitic Tropilaelaps mites (Acari: Laelapidae): New and re-defined species. Exp. Appl. Acarol. 2007, 43, 1-24. [CrossRef]

40. De Guzman, L.I.; Williams, G.R.; Khongphinitbunjong, K.; Chantawannakul, P. Ecology, life history, and management of Tropilaelaps mites. J. Econ. Entomol. 2017, 110, 319-332. [CrossRef]

41. Traynor, K.S.; Rennich, K.; Forsgren, E.; Rose, R.; Pettis, J.; Kunkel, G.; Madella, S.; Evans, J.; Lopez, D.; Van Engelsdorp, D. Multiyear survey targeting disease incidence in US honey bees. Apidologie 2016, 47, 325-347. [CrossRef]

42. Pettis, J.S.; Rose, R.; Lichtenberg, E.M.; Chantawannakul, P.; Buawangpong, N.; Somana, W.; Sukumalanand, P.; Vanengelsdorp, D. A rapid survey technique for Tropilaelaps mite (Mesostigmata: Laelapidae) detection. J. Econ. Entomol. 2013, 106, 1535-1544. [CrossRef] [PubMed]

43. Utzeri, V.J.; Ribani, A.; Schiavo, G.; Bertolini, F.; Bovo, S.; Fontanesi, L. Application of next generation semiconductor based sequencing to detect the botanical composition of monofloral, polyfloral and honeydew honey. Food Control 2018, 86, 342-349. [CrossRef]

44. Utzeri, V.J.; Ribani, A.; Fontanesi, L. Authentication of honey based on a DNA method to differentiate Apis mellifera subspecies: Application to Sicilian honey bee (A. m. siciliana) and Iberian honey bee (A. m. iberiensis) honeys. Food Control 2018, 91, 294-301. [CrossRef]

45. Utzeri, V.J.; Schiavo, G.; Ribani, A.; Bertolini, F.; Bovo, S.; Fontanesi, L. A next generation sequencing approach for targeted Varroa destructor (Acari: Varroidae) mitochondrial DNA analysis based on honey derived environmental DNA. J. Invertebr. Pathol. 2019, 161, 47-53. [CrossRef]

46. Han, S.H.; Lee, D.B.; Lee, D.W.; Kim, E.H.; Yoon, B.S. Ultra-rapid real-time PCR for the detection of Paenibacillus larvae, the causative agent of American foulbrood (AFB). J. Invertebr. Pathol. 2008, 99, 8-13. [CrossRef]

47. Arai, R.; Miyoshi-Akiyama, T.; Okumura, Y.; Morinaga, K.; Wu, M.; Sugimura, Y.; Yoshiyama, M.; Okura, M.; Kirikae, T.; Takamatsu, D. Development of duplex PCR assay for detection and differentiation of typical and atypical Melissococcus plutonius strains. J. Vet. Med. Sci. 2014, 76, 491-498. [CrossRef]

48. Chen, Y.; Evans, J.D.; Zhou, L.; Boncristiani, H.; Kimura, K.; Xiao, T.; Litkowski, A.M.; Pettis, J.S. Asymmetrical coexistence of Nosema ceranae and Nosema apis in honey bees. J. Invertebr. Pathol. 2009, 101, 204-209. [CrossRef]

49. Kojima, Y.; Yoshiyama, M.; Kimura, K.; Kadowaki, T. PCR-based detection of a tracheal mite of the honey bee Acarapis woodi. J. Invertebr. Pathol. 2011, 108, 135-137. [CrossRef]

50. Garrido-Bailón, E.; Bartolomé, C.; Prieto, L.; Botías, C.; Martínez-Salvador, A.; Meana, A.; Martín-Hernández, R.; Higes, M. The prevalence of Acarapis woodi in Spanish honey bee (Apis mellifera) colonies. Exp. Parasitol. 2012, 132, 530-536. [CrossRef]

51. Kumar, S.; Stecher, G.; Li, M.; Knyaz, C.; Tamura, K. MEGA X: Molecular evolutionary genetics analysis across computing platforms. Mol. Biol. Evol. 2018, 35, 1547-1549. [CrossRef] [PubMed]

52. Hall, T.A. BioEdit: A user-friendly biological sequence alignment editor and analysis program for Windows 95/98/NT. Nucl. Acids Symp. Ser. 1999, 41, 95-98.

53. Ellis, J.D.; Munn, P.A. The worldwide health status of honey bees. Bee World 2005, 86, 88-101. [CrossRef]

54. Kojima, Y.; Toki, T.; Morimoto, T.; Yoshiyama, M.; Kimura, K.; Kadowaki, T. Infestation of Japanese native honey bees by tracheal mite and virus from non-native European honey bees in Japan. Microb. Ecol. 2011, 62, 895-906. [CrossRef] [PubMed]

55. Çakmak, I.; Aydın, L.; Gulegen, E.; Wells, H. Varroa (Varroa destructor) and tracheal mite (Acarapis woodi) incidence in the Republic of Turkey. J. Apic. Res. 2003, 42, 57-60. [CrossRef]

56. Adjlane, N.; Assia, H.C.; Haddad, N.; Ahcen, B. Prevalence of acariosis in honeybee colonies of Apis mellifera intermissa in Algeria. J. Entomol. Res. 2018, 42, 451-454. [CrossRef]

57. Ahn, A.J.; Ahn, K.S.; Noh, J.H.; Kim, Y.H.; Yoo, M.S.; Kang, S.W.; Yu, D.H.; Shin, S.S. Molecular prevalence of Acarapis mite infestations in honey bees in Korea. Korean J. Parasitol. 2015, 53, 315-320. [CrossRef]

58. Martín-Hernández, R.; Botías, C.; Bailón, E.G.; Martínez-Salvador, A.; Prieto, L.; Meana, A.; Higes, M. Microsporidia infecting Apis mellifera: Coexistence or competition. Is Nosema ceranae replacing Nosema apis. Environ. Microbiol. 2012, 14, 2127-2138. [CrossRef] 
59. Natsopoulou, M.E.; McMahon, D.P.; Doublet, V.; Bryden, J.; Paxton, R.J. Interspecific competition in honeybee intracellular gut parasites is asymmetric and favours the spread of an emerging infectious disease. Proc. $R$. Soc. B Biol. Sci. 2015, 282, 20141896. [CrossRef]

60. Emsen, B.; Guzman-Novoa, E.; Hamiduzzaman, M.M.; Eccles, L.; Lacey, B.; Ruiz-Pérez, R.A.; Nasr, M. Higher prevalence and levels of Nosema ceranae than Nosema apis infections in Canadian honey bee colonies. Parasitol. Res. 2016, 115, 175-181. [CrossRef]

61. Tritschler, M.; Retschnig, G.; Yañez, O.; Williams, G.R.; Neumann, P. Host sharing by the honey bee parasites Lotmaria passim and Nosema ceranae. Ecol. Evol. 2017, 7, 1850-1857. [CrossRef] [PubMed]

62. Forsgren, E.; Lundhagen, A.C.; Imdorf, A.; Fries, I. Distribution of Melissococcus plutonius in honeybee colonies with and without symptoms of European foulbrood. Microb. Ecol. 2005, 50, 369-374. [CrossRef] [PubMed]

63. Belloy, L.; Imdorf, A.; Fries, I.; Forsgren, E.; Berthoud, H.; Kuhn, R.; Charrière, J.D. Spatial distribution of Melissococcus plutonius in adult honey bees collected from apiaries and colonies with and without symptoms of European foulbrood. Apidologie 2007, 38, 136-140. [CrossRef]

64. Haynes, E.; Helgason, T.; Young, J.P.W.; Thwaites, R.; Budge, G.E. A typing scheme for the honeybee pathogen Melissococcus plutonius allows detection of disease transmission events and a study of the distribution of variants. Environ. Microbiol. Rep. 2013, 5, 525-529. [CrossRef]

65. Antúnez, K.; D’Alessandro, B.; Piccini, C.; Corbella, E.; Zunino, P. Paenibacillus larvae larvae spores in honey samples from Uruguay: A nationwide survey. J. Invertebr. Pathol. 2004, 86, 56-58. [CrossRef]

66. Gillard, M.; Charriere, J.D.; Belloy, L. Distribution of Paenibacillus larvae spores inside honey bee colonies and its relevance for diagnosis. J. Invertebr. Pathol. 2008, 99, 92-95. [CrossRef]

(C) 2020 by the authors. Licensee MDPI, Basel, Switzerland. This article is an open access article distributed under the terms and conditions of the Creative Commons Attribution (CC BY) license (http://creativecommons.org/licenses/by/4.0/). 